\title{
Uso de criterios múltiples para introducir y clasificar los criterios de diseño de recompensa en proyectos de construcción
}

\section{Using multiple criteria to enter and rank reward design criteria in construction projects}

\author{
Masoud Koochakzadeh $^{1}$, Valiollah Azizifar ${ }^{2 a}$ \\ Ghaemshahr Branch, Islamic Azad University, Ghaemshahr, Iran ${ }^{12}$ \\ Orcid ID: https://orcid.org/0000-0002-2838-71691 \\ iD Orcid ID: https://orcid.org/0000-0003-4671-129X
}

Recibido: 04 de abril de 2020

Aceptado: 19 de octubre de 2020

\begin{abstract}
Resumen
El objetivo de este estudio fue el uso de la toma de decisiones de criterios múltiples para introducir y clasificar los criterios de diseño de recompensa en proyectos de construcción. En esta investigación se clasifican los criterios de diseño de recompensas en proyectos de construcción. En el presente estudio, para identificar y clasificar los criterios de asignación de recompensas a los empleados se utilizaron los métodos de Demetel y la expansión del desempeño de calidad difusa en dos pasos. Los resultados mostraron que la ética profesional es el criterio más importante para la asignación de recompensas a los empleados en los proyectos de construcción. Los resultados muestran que considerar el clima laboral de los proyectos de construcción, mantener la disciplina y tener compromiso organizacional y ayudar a los demás es muy importante. Además, tener el espíritu de trabajo en equipo y cooperación con los demás es muy importante para trabajar en estos entornos. Uno de los puntos destacables en los hallazgos de este estudio es la menor atención prestada por los gerentes de obra al uso de indicadores de medición de cantidad de mano de obra como criterio para la asignación de recompensas y mayor atención a criterios de calidad como la ética profesional, la creatividad, etc., que muestra la diferencia entre la naturaleza del trabajo y el producto final de esta industria con industrias manufactureras como la fabricación de piezas.
\end{abstract}

Palabras clave: Desempeño de calidad difusa, salarios del personal, análisis jerárquico, diseño de recompensas, proyectos de construcción

Abstract
The objective of this study was to The Use of Multi-Criteria Decision Making to Introduce and
Rank of Design Criteria of Reward in Construction Projects. In this research, the design criteria
of rewards in construction projects are ranked. In the present study, in order to identify and

${ }^{\mathrm{a}}$ Correspondencia al autor

E-mail: v.azizifar@gmail.com 
rank the criteria of employee reward allocation the methods of Demetel and expansion of the performance of fuzzy quality in two steps were used. the results showed that the professional ethics is the most important criterion for reward allocation to the employees in the construction projects. Results show that considering the work environment of construction projects, maintaining discipline and having organizational commitment and helping others is very important. Also, having the spirit of teamwork and cooperation with others is very important for working in such environments. One of the notable points in the findings of this study is the less attention paid by construction managers to the use of labor quantity measurement indicators as a criterion for reward allocation and more attention to quality criteria such as professional ethics, creativity, etc., which shows the difference between the nature of the work and the end product of this industry with manufacturing industries such as parts manufacturing.

Keywords: Fuzzy Quality Performance, Personnel Wages, Hierarchical Analysis, Reward Design, Construction Projects

\section{Introduction}

Undoubtedly, one of the effective ways to motivate and improve the productivity of employees and the performance of an organization is the existence of a system of service compensation and rewards fixed with the budget and revenues. The set of performance evaluation and reward system and effective wage, forms the performance management of an organization (Valipour, 2018).

The selection of an effective reward system is done in different ways, one of which is the performance-based payment method. the reward is also one of the types of performancebased payment that in various sectors of industry, both public and private, forms of It is available. Housing as one of the primary and basic living needs of human beings and households of a society in particular, and so the construction industry and its related jobs have a special rank in Iran economy today (Sepehri Rad, 2019). This industry has a share of 14.2\% of employees in the country based on annual statistics of 2017 except the part of the service sector that is indirectly related to it and is one of the thriving businesses in the country (Onishi, 2020).

Ontime delivery of projects, especially in the mass production sector, while having its special importance in the profitability of the project, in terms of fluctuations in the price of materials and wages of specialized works and compliance with the time table and schedule of contracts, also has significant political effects in gaining popular satisfaction and economic stability (Maslahi and Zafar Khan, 2019).

\section{Research background}

Nematbakhsh et al. (2016) examined the point of views of faculty members of the University of Medical Sciences of Tehran about the effects of reward system on medical 
education in teaching hospitals. In this cross-sectional study, 69 faculty members were interviewed and the results showed that the reward system has failed to promote medical education, so there is a need to review the reward system to improve medical education. In this study, the lack of a proper evaluation system has been identified as one of the main reasons for the failure of the reward system project.

Sepehri Rad (2019) has proposed a mathematical model of reward payment for employees of the organization with a 360-degree performance evaluation approach in the National Productivity Organization. In this study, at first the indicators of employee performance evaluation were extracted from the literature, then by a survey of experts and based on the characteristics of the studied organization and similar to Valipour (2018) study into four categories of personal characteristics, technical skills, human skills and perceptual skills has been divided.

Yang and Chen (2018) propose an incentive payment system for project management based on the responsibilities allocation matrix and fuzzy language variables. This study presents a new payment system for active team members in each project. Performance evaluation is performed without specifying a specific criterion and based on judgments made with the help of fuzzy linguistic variables. In this system, four models are proposed for different project management conditions.

Maslahi and Zafar Khan (2019) have studied the factors affecting the productivity of employees in construction projects and in spite of considering factors such as temperature, relative humidity, type of work and the method used. They have not pointed to the factors like payment and reward and its effect on the efficiency.

Chai (2019) by use of a combined approach of the methods of either fuzzy hierarchical analysis process and fuzzy TOPSIS has evaluated the performance of the employees of the studied organization. The criteria used in this study to evaluate employee performance are: production ability, ability to be creative and innovative, financial performance and how to serve customers.

Opheli (2019) in a study on construction companies operating in the Nigerian industry, considers the factors affecting the general reward systems as including the internal and external factors. Internal factors include organizational culture, organizational strategy and organizational life cycle. External factors also include the market, specialization, productivity indicators, and human-personnel relations activities. He also suggests the factors affecting on payment based on performance as the performance evaluation, education and development, union-manager relations, and organizational culture. In this study, the determinant factors of 
reward policy include labor market conditions, laws, productivity, collective bargaining, cost of living, employer financial ability, comparable wages, industry, staff level, and minimum wage for life.

Lai et al. (2020) conducted a comparative study about the impact of human resource operations, including performance and reward evaluation and reward, in safety management in construction projects in the United States and Singapore. Based on this research, criteria such as reporting unsafe or dangerous actions, fewer accidents, individual safety performance and group safety performance have been selected as criteria for rewarding the safety management of construction projects. The results show that evaluating the performance of employees in terms of safety and rewarding employees based on their safety performance is effective on the safety management of construction projects.

Cornellison et al. (2020) in their research show that employee satisfaction was higher in jobs where performance-based pay was implemented than in other jobs. They then propose a model in which employees with greater ability and higher risk tolerance receive greater rewards through performance-based pay. With the implementation of this model, employee satisfaction was assessed equally in all jobs, but employees in jobs that were paid based on performance and had a higher risk tolerance, expressed higher satisfaction.

Onishi (2020) examines the effects of service compensation schemes on Research and Developement Organization of Japan staff innovations. In this research, the evaluation criterion is the criteria based on income and innovation and the results show that monetary incentives based on the performance of inventions, lead to increasing the motivation of innovative employees.

\section{Methodology}

In the present study, which is performed in order to both identification and ranking the criteria of the reward allocation by use of DEMATEL and expansion of fuzzy quality performance in two stages, the statistical population includes the senior managers and human resources managers of the construction companies that are implementing the reward plan or are at first steps of this implementation.

In this study, due to the limited number of experts as well as senior managers of the studied construction organizations where were implementing the reward plan, the available sampling method is used. Due to the fact that the statistical population of the research is limited to experts with experience in the field of service compensation systems, reward systems and 
the senior managers responsible for decision making and planning in the organization under study, research questionnaires are distributed among all eligible individuals. And all of them will be questioned.

\section{Research steps}

Figure 1 shows the steps of conducting research.

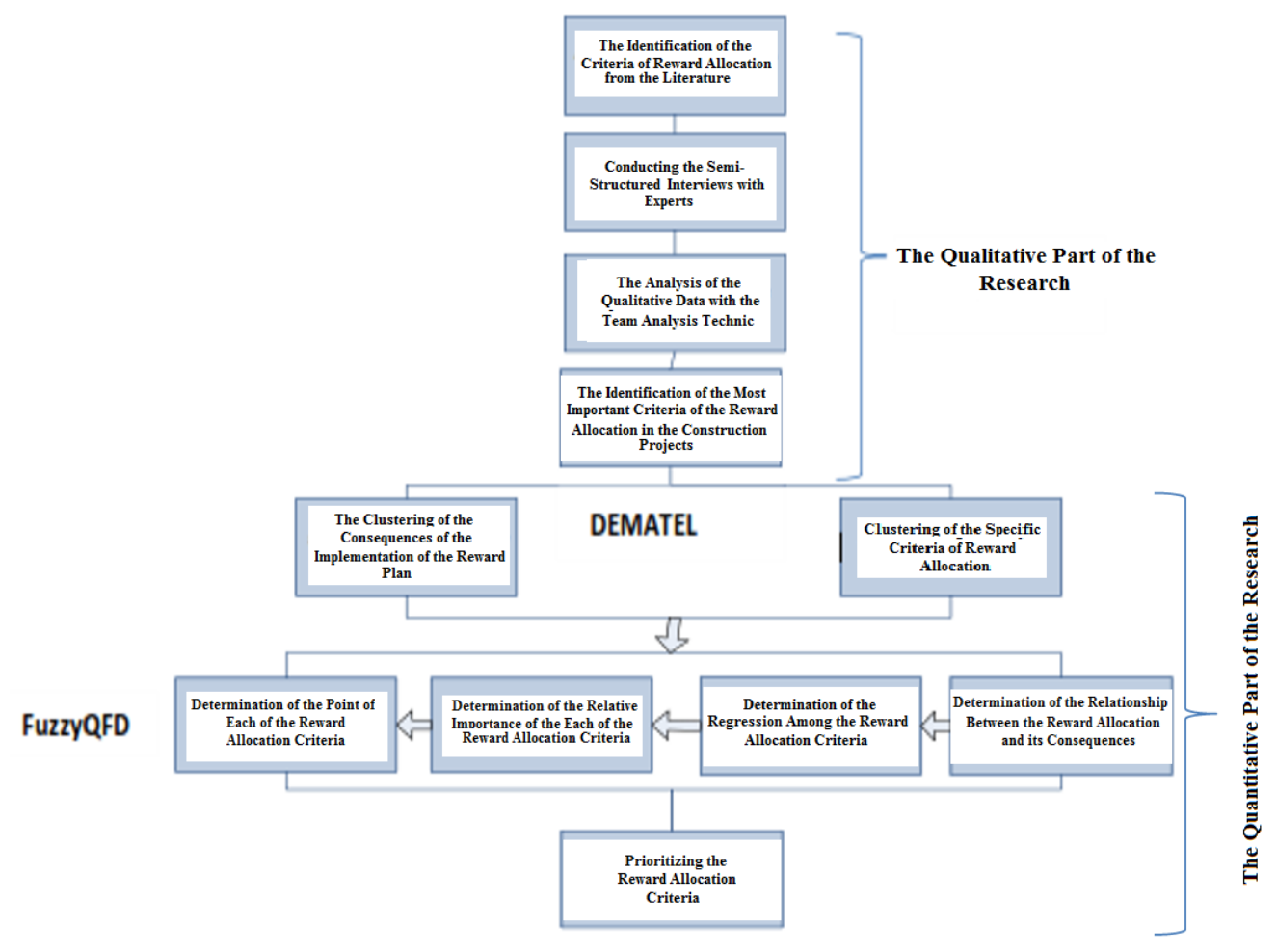

The steps of this research

Figure 1

\section{Validity and reliability of research}

\section{Validity:}

To increase the validity and reliability of the theme analysis, the following method is used in this research:

Triangular method: In this method, several researchers, several data sources, or several methods are used to validate emerging data. In this research, by choosing a mixed method and using the literature and opinions of experts, we try to increase the validity of the obtained model.

\section{Reliability:}

To determine the reliability of the researches such as the present study, much of which is qualitative, there is no need to determine reliability in the form of statistical research, but to 
ensure that the results are reliable, especially after theme analysis, there are three methods. (Maryam, 1988) Used:

- Triangulation: In this method, similar to what is used to confirm validity, it is also used to confirm reliability. This means that the use of mixed research method can show the reliability of research findings.

- Auditing by an arbitrator: In this method, the researcher increases the reliability of the research results by clarifying how to collect data, how categories are derived and how to make a decision during the investigation for the auditor and its approval by the arbitrator. In this research, this audit is performed by the professors.

- Retest method: To conduct the retest method, three interviews are selected and each of them is coded twice in a period of 20 days by the researcher. Then the retest reliability percentage is calculated by use of the equation 1. In this study, this number was equal to $78 \%$, which was more than the minimum acceptable value of $60 \%$.

Equation 1:

$$
\text { Retest reliability percent }=\frac{2 * \text { The number of agreements }}{\text { The final number of Codes }} * 100 \%
$$

\section{Data analysis tools}

\section{Qualitative data analysis}

In this research, in order to analyze the qualitative data obtained from the interviews, the theme analysis method is used. Theme analysis is a method of determining, analyzing, and expressing patterns (themes) within data. This method, at a minimum, organizes the data and describes it in detail. But it can go beyond this and interpret different aspects of the research topic. The six stages of theme analysis are described below (Clark and Brown, 2016):

Step 1. Prepare and familiarize with the data: Before analyzing the data, the data should be easy to work with.

Step 2. Creating the initial codes: The second step begins when the researcher has organized, read, and become familiar with the data.

Step 3. Search for Themes: This step involves categorizing different codes into potential themes, and sorting all the summaries of the encoded data into specified themes. 
Step 4. Creating meanings and concepts: In this stage, the researcher needs to move more freely and have a productive and exciting mind.

2-5-3- Quantitative Data Analysis:

In the present study in order to the analysis of the quantitative data, two multi- criterion decision making methods were used that are explained as below in the framework of data analyzing steps:

\section{DEMATEL Method}

Gabus and Fontla (1972) suggest a method for DEMATEL implementation that has been used in the present study. The output of the noted method in this study, is the identification of the most important criteria of reward allocation and expected consequences of the reward plan among the identified factors and consequences in order to go inside the qualitative blanks of the approach of the expansion of Fuzzy qualitative performance.

- In the first step, the initial direct relation matrix $A=$ [aij] is formed using the opinions of experts. Where $\mathrm{A}$ is a non-negative matrix $\mathrm{n} \times \mathrm{n}$ and aij represents the direct effect of factor $\mathrm{i}$ on factor $\mathrm{j}$.

In the second step, the initial direct relationship matrix must be normalized. The normalized direct relation matrix is obtained from Equation 2.

$$
D=\frac{1}{\max \sum_{1 \leq i \leq n}^{n} a_{i j}} A
$$

In the third step, using Equation 3, we obtain the total relational matrix T. The tij component represents the indirect effects of factor $i$ on factor $j$.

$T=D(I-D)^{-1}$

- In the fourth step, the sum of the rows and columns of the matrix $\mathrm{T}$ is calculated. ri and cj are obtained through equations 4 and 5, respectively.

$$
\begin{aligned}
& I_{1}=\sum_{1 \leq j \leq n} t_{i j} \\
& c_{j}=\sum_{1 \leq i \leq n} t_{i j}
\end{aligned}
$$


- In the fifth step, by calculating the values of ri + ci and ri-ci, causal and influential factors and disabled factors are identified.

- In the sixth step, the causal relationship diagram is made based on the values of ri + ci and ri-ci.

\section{Scope of Research}

This research started from the beginning of spring 2019 and lasted until the end of summer 2019.The location of research is a number of construction companies in Mashhad city that have used the reward plan or intend to implement the reward plan. The specialty of this research is human resource management. In this research, the most important criteria for reward allocation in construction companies and their relationship with the consequences of the implementation of this project in construction companies are examined.

\section{Results}

After a comprehensive review of the literature and research background, the most important identified criteria for reward allocation are presented in Table 1. 


\section{Table 1}

Identified criteria for reward allocation of research literature

\begin{tabular}{|c|c|}
\hline $\begin{array}{l}\text { The Criterion of Reward } \\
\text { Allocation }\end{array}$ & Research \\
\hline The quantity of Duty & $\begin{array}{l}\text { Mozaffar (1996) Yousefpoor (1998) Rahbari (2000) Vafaee } \\
\text { (2000) Alem Tabriz (2002) Metis and Jackson (2009) De Senzo } \\
\text { and Robins (1998) Chai (2010) }\end{array}$ \\
\hline The quality of Duty & $\begin{array}{l}\text { Royaee (1991) Yoosefpoor (1998) Rahbari (2000) Vafaee } \\
\text { (2000) Tizro (2001) Alem Tabriz (2002) Metis and Jackson } \\
\text { (2009) Aplbam and Shapiro (1992) }\end{array}$ \\
\hline The hours of presence & $\begin{array}{l}\text { Sa'adat (2007) Metis and Jackson (2009) De Senzo and Robins } \\
\text { (1998) }\end{array}$ \\
\hline Collaboration and Team working & $\begin{array}{l}\text { Metis and Jackson (2009) Sepehri Rad (2011) De Senzo and } \\
\text { Robins (1998) }\end{array}$ \\
\hline Effectiveness & Royaee (1992) Taheri (2003) Wang (2004) \\
\hline Performance & $\begin{array}{l}\text { Royaee (1992) Vafaee (2000) Alem Tabriz (2002) Taheri } \\
\text { (2003) Saadat (2007) Sepehri Rad (2011) }\end{array}$ \\
\hline Profitability & Royaee (1992) Anvari Rostami( 2001) Chai ( 2001) \\
\hline Efficiency & $\begin{array}{l}\text { Royaee (1992) Anvari Rostami( 2001) Alem Tabriz ( 2002) Li } \\
\text { wan (2007) Onishi ( 2013) }\end{array}$ \\
\hline Job and work Experience & Rahbari (2000) Vafaee (2000) Tizro (2001) Alem Tabriz (2002) \\
\hline Job Condition & $\begin{array}{l}\text { Alem Tabriz (2002) Taheri (2003) Sa'adat (2007) Moslehi and } \\
\text { ZafarKhan (2010) }\end{array}$ \\
\hline Discipline & $\begin{array}{l}\text { Vafaee (2000) Tizro (2001) Alem Tabriz (2002) Sepehri Rad } \\
\text { (2011) }\end{array}$ \\
\hline Innovation & $\begin{array}{l}\text { Yoosefpoor (1998) Tizro (2001) Alem Tabriz (2002) Taheri } \\
\text { (2003) Sepehri Rad (2011) De Senzo and Robins (1998) Chai } \\
\text { (2010) Onishi (2013) }\end{array}$ \\
\hline Skill and Knowledge & $\begin{array}{l}\text { Yoosefpoor (1998) Seyed Javadin (2003) Sa'adat (2007) } \\
\text { Sepehri Rad (2011) De Senzo and Robins (1998) Cornilson et } \\
\text { al. (2011) }\end{array}$ \\
\hline Profession Ethics & $\begin{array}{l}\text { Tizro (2001) Sepehri Rad (2011) De Senzo and Robins (1998) } \\
\text { Li wan (2007) }\end{array}$ \\
\hline Interested persons satisfaction & Rahbari (2000) Tizro (2001) Chai (2010) \\
\hline Graduation & Rahbari (2000) Vafaee (2000) Tizro (2001) \\
\hline
\end{tabular}

\section{Qualitative part of the research}

By reviewing the results of literature review and analyzing the data obtained from interviews, eight criteria for reward allocation and ten consequences of reward plan implementation were identified, which are presented in Tables 2 and 3 below. Criteria and consequences are introduced in these tables, which in addition to the results of data analysis, have been approved by various research literature. 


\section{Table 2}

Final criteria for reward allocation in construction projects (extracted from the qualitative part of research)

\begin{tabular}{|c|c|c|c|c|c|c|c|c|c|c|}
\hline \multirow[t]{2}{*}{ Tag } & \multirow{2}{*}{ Criterion } & \multirow[t]{2}{*}{ Researcher } & \multicolumn{4}{|c|}{ Interview } & \multirow[b]{2}{*}{5} & \multirow[b]{2}{*}{6} & \multirow[b]{2}{*}{7} & \multirow[b]{2}{*}{8} \\
\hline & & & 12 & 2 & 3 & 4 & & & & \\
\hline C1 & $\begin{array}{l}\text { Project } \\
\text { performance }\end{array}$ & $\begin{array}{l}\text { Royaee (1992) Vafaee }(2000) \\
\text { Alem Tabriz (2002) Taheri } \\
\text { (2003) Saadat (2007) Sepehri Rad } \\
\text { (2011) }\end{array}$ & $*$ & & & & $*$ & $*$ & $*$ & $*$ \\
\hline $\mathrm{C2}$ & Doing Duties & $\begin{array}{l}\text { Royaee (1991) Taheri (2003) } \\
\text { Wang (2014) } \\
\text { Li Wan (2017) Onishi (2020) }\end{array}$ & & $*$ & $*$ & * & * & & $*$ & \\
\hline C3 & $\begin{array}{l}\text { creativity } \\
\text { and } \\
\text { innovation }\end{array}$ & $\begin{array}{l}\text { Yoosefpoor (1998) Tizro (2001) } \\
\text { Alem Tabriz (2002) Taheri } \\
\text { (2003) Sepehri Rad (2011) De } \\
\text { Senzo and Robins (1998) Chai } \\
\text { (2010) Onishi (2013) }\end{array}$ & $*$ & & $*$ & & & & & * \\
\hline $\mathrm{C} 4$ & team work & $\begin{array}{l}\text { Metis and Jackson (2009) Sepehri } \\
\text { Rad (2011) De Senzo and Robins } \\
\text { (1998) }\end{array}$ & & & & & & * & & * \\
\hline C5 & $\begin{array}{l}\text { Satisfaction } \\
\text { of } \\
\text { stakeholders }\end{array}$ & $\begin{array}{l}\text { Rahbari (2000) Tizro (2001) Chai } \\
\text { (2010) }\end{array}$ & & & & * & * & & & \\
\hline C6 & $\begin{array}{l}\text { Knowledge } \\
\text { and ability } \\
\text { to use it }\end{array}$ & $\begin{array}{l}\text { Yoosefpoor } \quad(1998) \\
\text { Javadin (2003) Sa'adat } \\
\text { Sepehri Rad (2011) De Senzo and } \\
\text { Robins (1998) Cornilson et al } \\
(2011)\end{array}$ & $*$ & & & & & * & & \\
\hline C7 & $\begin{array}{l}\text { Profitability } \\
\text { And value } \\
\text { creation }\end{array}$ & $\begin{array}{l}\text { Royaee (1992) Anvari Rostami } \\
\text { (2001) Metis and Jackson (2018) } \\
\text { Aplbam and Shapiro (1992) }\end{array}$ & $*$ & & $*$ & & & & $*$ & $*$ \\
\hline $\mathrm{C8}$ & $\begin{array}{l}\text { Professional } \\
\text { Ethics }\end{array}$ & $\begin{array}{l}\text { Vafaee (2000) Tizro (2001) Alem } \\
\text { Tabriz (2002) Sepehri Rad (2011) } \\
\text { De Senzo and Robins (1998) Li } \\
\text { wan (2017) }\end{array}$ & * & & & & & * & & \\
\hline
\end{tabular}




\section{Table 3}

Expected consequences of the implementation of the reward plan in construction projects (extracted from the qualitative part of the research)

\begin{tabular}{|c|c|c|c|c|c|c|c|c|c|c|}
\hline \multirow[t]{2}{*}{ Tag } & \multirow{2}{*}{ Criterion } & \multirow{2}{*}{ research fellow } & \multicolumn{8}{|c|}{ interview } \\
\hline & & & 1 & 2 & 3 & 4 & 5 & 6 & 7 & 8 \\
\hline 01 & $\begin{array}{l}\text { Increase } \\
\text { employee } \\
\text { motivation and } \\
\text { job satisfaction }\end{array}$ & $\begin{array}{l}\text { Mozaffari(1996) Yoosefpoor( } \\
\text { 1998) Abdol Abadi et al( } \\
\text { 2005) Cornilson et al ( 2020) } \\
\text { Onishi( 2020) }\end{array}$ & $*$ & $*$ & & $*$ & $*$ & $*$ & $*$ & $*$ \\
\hline $\mathrm{O2}$ & $\begin{array}{l}\text { Establishment } \\
\text { organizational } \\
\text { justice }\end{array}$ & $\begin{array}{l}\text { Yoosefpoor( 1998) } \\
\text { AbdolAbadi et al( 2005) }\end{array}$ & $*$ & & $*$ & & & & $*$ & $*$ \\
\hline $\mathbf{O 3}$ & $\begin{array}{l}\text { Improvement } \\
\text { of customer } \\
\text { and } \\
\text { stakeholder } \\
\text { satisfaction }\end{array}$ & Tizro( 2000) & & & $*$ & & & & & \\
\hline O4 & $\begin{array}{l}\text { Improve } \\
\text { effectiveness }\end{array}$ & $\begin{array}{l}\text { Yosefpoor( 1998) Tizro ( } \\
\text { 2000) }\end{array}$ & & & & $*$ & & $*$ & $*$ & \\
\hline O5 & $\begin{array}{l}\text { Increasing } \\
\text { safety }\end{array}$ & $\begin{array}{l}\text { Mozaffari ( 1995) Tizro ( } \\
\text { 2000) Lai et al ( 2020) }\end{array}$ & & & & & & $*$ & & \\
\hline O6 & $\begin{array}{l}\text { Promoting } \\
\text { creativity and } \\
\text { innovation }\end{array}$ & $\begin{array}{l}\text { Shimon and Rendal( } 1999) \\
\text { Agrel et al ( 2002) Onishi } \\
(2020)\end{array}$ & $*$ & & & & & & & \\
\hline O7 & $\begin{array}{l}\text { Improving } \\
\text { Performance }\end{array}$ & $\begin{array}{l}\text { Yoosefpoor (1998) Tizro( } \\
\text { 2001) Agrel et al( 2002) }\end{array}$ & & $*$ & & $*$ & & $*$ & $*$ & $*$ \\
\hline O8 & $\begin{array}{l}\text { Increase } \\
\text { profitability }\end{array}$ & $\begin{array}{l}\text { Shimon and Rendal ( 1998) } \\
\text { Desler( 1999) }\end{array}$ & $*$ & $*$ & & & & & & \\
\hline O9 & $\begin{array}{l}\text { Staff learning } \\
\text { and personal } \\
\text { growth }\end{array}$ & Agrel ( 2002) & & & & $*$ & & & & \\
\hline
\end{tabular}

\section{Clustering and identifying the most effective criteria and consequences}

\section{Clustering of reward allocation criteria}

In this part of the research, the 8 reward allocation criteria obtained in the qualitative part of the research are clustered using the Demetel method to identify the final and causal reward allocation criteria. In addition to clustering, data analysis using DEMETEL helps to evaluate the relationships and interrelationships between reward allocation criteria. In this step, the criteria are divided into two groups of cause and effect factors, and the cause criteria are entered due to the greater importance of the ranking process by using fuzzy quality performance expansion. In the following, data analysis using DEMETEL method is presented. 


\section{Formation of direct impact matrix of reward allocation criteria}

In this step, first, using the criteria presented in Table 2, experts were asked to determine the impact of each criterion on other criteria, by use of the numbers 0 (no effect), 1 (Low impact), 2 (high impact) and 3 (very high impact) in order to determine the effects of each of criteria on the other creteria. Then by use of the arithmetic mean to we reached summarize the opinions of experts ( $\mathrm{Wu}, 2018)$. Table 4 summarizes the 8 expert opinions that were interviewed in the qualitative section, and in fact the matrix shows the direct impact. This summation is calculated using Equation 6. In this regard, $\mathrm{n}$ is the number of criteria and $\mathrm{m}$ is the number of experts.

6

$$
\mu=\frac{\sum_{\substack{k=1 \\ 1 \leq i \leq n \\ 1 \leq j \leq n}}^{m} a_{i j k}}{m}
$$


Table 4

Summary of expert opinions using arithmetic mean (direct impact matrix) for reward allocation criteria

\begin{tabular}{|c|c|c|c|c|c|c|c|c|}
\hline Factors & $\begin{array}{l}\text { Projec } \\
t \\
\text { perfor } \\
\text { mance } \\
\left(C_{1}\right)\end{array}$ & $\begin{array}{l}\text { Duty } \\
\left(\mathrm{C}_{2}\right)\end{array}$ & $\begin{array}{l}\text { Cretivity } \\
\text { and } \\
\text { Innovati } \\
\text { on } \\
\left(\mathrm{C}_{3}\right)\end{array}$ & $\begin{array}{l}\text { Team } \\
\text { Work } \\
\left(C_{4}\right)\end{array}$ & $\begin{array}{l}\text { Stakeho } \\
\text { lders } \\
\text { satisfact } \\
\text { ion } \\
\left(C_{5}\right)\end{array}$ & $\begin{array}{l}\text { Knowled } \\
\text { ge and } \\
\text { ability to } \\
\text { use it } \\
\left(C_{6}\right)\end{array}$ & $\begin{array}{l}\text { Profita } \\
\text { bility } \\
\text { and } \\
\text { Value } \\
\text { creatio } \\
\text { n } \\
\left(C_{7}\right)\end{array}$ & $\begin{array}{l}\text { Prof } \\
\text { essio } \\
\text { nal } \\
\text { Ethi } \\
\text { cs } \\
\left(\mathrm{C}_{8}\right)\end{array}$ \\
\hline $\begin{array}{l}\text { Project } \\
\text { performance } \\
\left(C_{1}\right)\end{array}$ & 0.000 & 1.000 & 1.000 & 2.125 & 3.000 & 1.000 & 2.500 & $\begin{array}{l}1.12 \\
5\end{array}$ \\
\hline $\begin{array}{l}\text { Duty } \\
\left(\mathbf{C}_{2}\right)\end{array}$ & 3.000 & 0.000 & 1.125 & 1.500 & 3.000 & 1.000 & 2.125 & $\begin{array}{l}1.00 \\
0\end{array}$ \\
\hline $\begin{array}{l}\text { Cretivity and } \\
\text { Innovation } \\
\left(\mathbf{C}_{3}\right)\end{array}$ & 3.000 & 2.000 & 0.000 & 1.500 & 2.125 & 2.000 & 3.000 & $\begin{array}{l}2.00 \\
0\end{array}$ \\
\hline $\begin{array}{l}\text { Team Work } \\
\left(\mathbf{C}_{4}\right)\end{array}$ & 2.125 & 2.500 & 2.000 & 0.000 & 2.000 & 1.000 & 2.500 & $\begin{array}{l}2.00 \\
0\end{array}$ \\
\hline $\begin{array}{l}\text { Stakeholders } \\
\text { Satisfaction } \\
\left(\mathbf{C}_{5}\right)\end{array}$ & 1.000 & 1.000 & 1.000 & 2.000 & 0.000 & 1.000 & 2.000 & $\begin{array}{l}2.00 \\
0\end{array}$ \\
\hline $\begin{array}{l}\text { Knowledge and } \\
\text { ability to use it } \\
\left(\mathrm{C}_{6}\right)\end{array}$ & 2.000 & 3.000 & 3.000 & 1.500 & 2.125 & 0.000 & 3.000 & $\begin{array}{l}2.00 \\
0\end{array}$ \\
\hline $\begin{array}{l}\text { Profitability } \\
\text { and Value } \\
\text { creation } \\
\left(\mathbf{C}_{7}\right)\end{array}$ & 2.000 & 1.000 & 1.000 & 1.000 & 3.000 & 1.000 & 0.000 & $\begin{array}{l}1.00 \\
0\end{array}$ \\
\hline $\begin{array}{l}\text { Professional } \\
\text { Ethics } \\
\left(\mathrm{C}_{8}\right)\end{array}$ & 2.000 & 3.000 & 1.500 & 3.000 & 2.500 & 2.000 & 2.000 & $\begin{array}{l}0.00 \\
0\end{array}$ \\
\hline
\end{tabular}

\section{Formation of normalized direct impact matrix of reward allocation criteria}

In this step, the direct effect matrix is normalized using the equation 2 . Table 5 shows the normalized direct impact matrix. 
Table 5

Normalized direct impact matrix

\begin{tabular}{lllllllll}
\hline Factors & $\mathbf{C}_{\boldsymbol{1}}$ & $\mathbf{C}_{\mathbf{2}}$ & $\mathbf{C}_{\mathbf{3}}$ & $\mathbf{C}_{\mathbf{4}}$ & $\mathbf{C}_{\mathbf{5}}$ & $\mathbf{C}_{\mathbf{6}}$ & $\mathbf{C}_{\mathbf{7}}$ & $\mathbf{C}_{\mathbf{8}}$ \\
\hline $\mathbf{C}_{\mathbf{1}}$ & 0 & 0.0602 & 0.0602 & 0.1278 & 0.1805 & 0.0602 & 0.1504 & 0.0677 \\
$\mathbf{C}_{\mathbf{2}}$ & 0.1805 & 0 & 0.0677 & 0.0902 & 0.1805 & 0.0602 & 0.1278 & 0.0602 \\
$\mathbf{C}_{\mathbf{3}}$ & 0.1805 & 0.1203 & 0 & 0.0902 & 0.1278 & 0.1203 & 0.1805 & 0.1203 \\
$\mathbf{C}_{\mathbf{4}}$ & 0.1278 & 0.1504 & 0.1203 & 0 & 0.1203 & 0.0602 & 0.1504 & 0.1203 \\
$\mathbf{C}_{\mathbf{5}}$ & 0.0602 & 0.0602 & 0.0602 & 0.1203 & 0 & 0.0602 & 0.1203 & 0.1203 \\
$\mathbf{C}_{\mathbf{6}}$ & 0.1203 & 0.1805 & 0.1805 & 0.0902 & 0.1278 & 0 & 0.1805 & 0.1203 \\
$\mathbf{C}_{\mathbf{7}}$ & 0.1203 & 0.0602 & 0.0602 & 0.0602 & 0.1805 & 0.0602 & 0 & 0.0602 \\
$\mathbf{C}_{\mathbf{8}}$ & 0.1203 & 0.1805 & 0.0902 & 0.1805 & 0.1504 & 0.1203 & 0.1203 & 0
\end{tabular}

Formation of the total impact matrix of all reward allocation criteria

In this step, the total effect matrix is calculated using the equation 3. Table 6 shows the total direct impact matrix.

Table 6

Total Matrix

\begin{tabular}{lllllllll}
\hline Factors & $\mathbf{C}_{\mathbf{1}}$ & $\mathbf{C}_{\mathbf{2}}$ & $\mathbf{C}_{\mathbf{3}}$ & $\mathbf{C}_{\mathbf{4}}$ & $\mathbf{C}_{\mathbf{5}}$ & $\mathbf{C}_{\mathbf{6}}$ & $\mathbf{C}_{\mathbf{7}}$ & $\mathbf{C}_{\mathbf{8}}$ \\
\hline $\mathbf{C}_{\mathbf{1}}$ & 0.3381 & 0.3513 & 0.2972 & 0.4127 & 0.5696 & 0.2672 & 0.5181 & 0.3289 \\
$\mathbf{C}_{\mathbf{2}}$ & 0.5195 & 0.3099 & 0.3176 & 0.4038 & 0.6013 & 0.2812 & 0.5274 & 0.3386 \\
$\mathbf{C}_{\mathbf{3}}$ & 0.6134 & 0.5016 & 0.3210 & 0.4812 & 0.6679 & 0.3905 & 0.6728 & 0.4563 \\
$\mathbf{C}_{\mathbf{4}}$ & 0.5333 & 0.4918 & 0.3978 & 0.3636 & 0.6128 & 0.3158 & 0.6018 & 0.4255 \\
$\mathbf{C}_{\mathbf{5}}$ & 0.3670 & 0.3299 & 0.2763 & 0.3792 & 0.3729 & 0.2496 & 0.4561 & 0.3462 \\
$\mathbf{C}_{\mathbf{6}}$ & 0.6024 & 0.5800 & 0.5004 & 0.5066 & 0.7054 & 0.3048 & 0.7094 & 0.4813 \\
$\mathbf{C}_{\mathbf{7}}$ & 0.3986 & 0.3095 & 0.2633 & 0.3180 & 0.5141 & 0.2390 & 0.3343 & 0.2864 \\
$\mathbf{C}_{\mathbf{8}}$ & 0.5819 & 0.5692 & 0.4175 & 0.5682 & 0.7010 & 0.3984 & 0.6412 & 0.3630 \\
\hline
\end{tabular}

Determining the internal relations of reward allocation criteria

In this step, we first calculate the values ri + ci and ri-ci using equations 4 and 5. Tables 7 and 8 show these values for each criterion. Then, based on the obtained values, we draw the causal diagram of the reward allocation criteria, which is shown in Figure 3-4. After calculating the values ri + ci and ri-ci, the causal diagram you see in Figure 4 is drawn. 


\section{Table 7}

The values of $r$ and $c$ for each factor

\begin{tabular}{llllllllll}
\hline Factors & $\mathbf{C}_{\boldsymbol{1}}$ & $\mathbf{C}_{\boldsymbol{2}}$ & $\mathbf{C}_{\boldsymbol{3}}$ & $\mathbf{C}_{\boldsymbol{4}}$ & $\mathbf{C}_{\boldsymbol{5}}$ & $\mathbf{C}_{\boldsymbol{6}}$ & $\mathbf{C}_{\mathbf{7}}$ & $\mathbf{C}_{\mathbf{8}}$ & $\mathbf{r}$ \\
\hline $\mathbf{C}_{\mathbf{1}}$ & 0.3381 & 0.3513 & 0.2972 & 0.4127 & 0.5696 & 0.2672 & 0.5181 & 0.3289 & $\mathbf{3 . 0 8 3 1}$ \\
$\mathbf{C}_{\mathbf{2}}$ & 0.5195 & 0.3099 & 0.3176 & 0.4038 & 0.6013 & 0.2812 & 0.5274 & 0.3386 & $\mathbf{3 . 2 9 9 3}$ \\
$\mathbf{C}_{\mathbf{3}}$ & 0.6134 & 0.5016 & 0.321 & 0.4812 & 0.6679 & 0.3905 & 0.6728 & 0.4563 & $\mathbf{4 . 1 0 4 7}$ \\
$\mathbf{C}_{\boldsymbol{4}}$ & 0.5333 & 0.4918 & 0.3978 & 0.3636 & 0.6128 & 0.3158 & 0.6018 & 0.4255 & $\mathbf{3 . 7 4 2 4}$ \\
$\mathbf{C}_{\boldsymbol{5}}$ & 0.367 & 0.3299 & 0.2763 & 0.3792 & 0.3729 & 0.2496 & 0.4561 & 0.3462 & $\mathbf{2 . 7 7 7 2}$ \\
$\mathbf{C}_{\mathbf{6}}$ & 0.6024 & 0.58 & 0.5004 & 0.5066 & 0.7054 & 0.3048 & 0.7094 & 0.4813 & $\mathbf{4 . 3 9 0 3}$ \\
$\mathbf{C}_{\boldsymbol{7}}$ & 0.3986 & 0.3095 & 0.2633 & 0.318 & 0.5141 & 0.239 & 0.3343 & 0.2864 & $\mathbf{2 . 6 6 3 2}$ \\
$\mathbf{C}_{\mathbf{8}}$ & 0.5819 & 0.5692 & 0.4175 & 0.5682 & 0.701 & 0.3984 & 0.6412 & 0.363 & $\mathbf{4 . 2 4 0 4}$ \\
$\mathbf{C}$ & $\mathbf{3 . 9 5 4 2}$ & $\mathbf{3 . 4 4 3 2}$ & $\mathbf{2 . 7 9 1 1}$ & $\mathbf{3 . 4 3 3 3}$ & $\mathbf{4 . 7 4 5}$ & $\mathbf{2 . 4 4 6 5}$ & $\mathbf{4 . 4 6 1 1}$ & $\mathbf{3 . 0 2 6 2}$ & - \\
\hline
\end{tabular}

Table 8

$r i+c i$ and ri-ci values

\begin{tabular}{lll}
\hline Factors & $\mathrm{R}_{\mathrm{i}}+\mathrm{c}_{\mathrm{i}}$ & $\mathrm{r}_{\mathrm{i}}-\mathrm{c}_{\mathrm{i}}$ \\
\hline $\mathbf{C}_{\mathbf{1}}$ & 7.0373 & -0.8711 \\
$\mathbf{C}_{\mathbf{2}}$ & 6.7425 & -0.1439 \\
$\mathbf{C}_{\mathbf{3}}$ & 6.8958 & 1.3136 \\
$\mathbf{C}_{\mathbf{4}}$ & 7.1757 & 0.3091 \\
$\mathbf{C}_{5}$ & 7.5222 & -1.9678 \\
$\mathbf{C}_{6}$ & 6.8368 & 1.9438 \\
$\mathbf{C}_{7}$ & 7.1243 & -1.7979 \\
$\mathbf{C}_{\mathbf{8}}$ & 7.2666 & 1.2142 \\
\hline
\end{tabular}

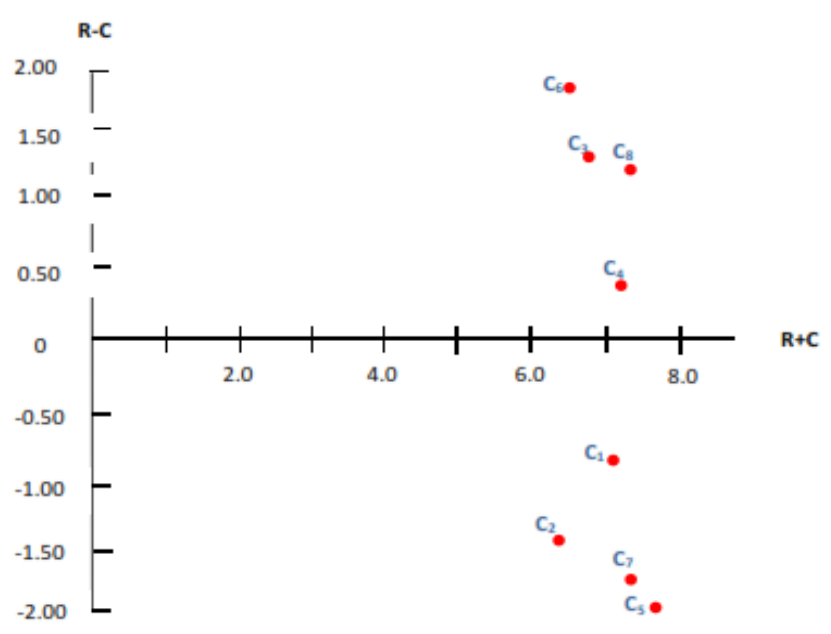

Figure 2

Causal diagram of reward allocation criteria 
The results of data analysis at this stage show that according to ri + ci values, stakeholder satisfaction (C5), professional ethics (C8), teamwork (C4) and profitability and value creation (C7) are the factors which have both a high impact on other criteria and a high impact from other criteria. But the factors of creativity and innovation (C3), teamwork (C4), knowledge and ability to use it (C6) and professional ethics (C8) according to the positive values of ri-ci, are located in the cluster of causal criteria. Also, the factors of project performance (C1), task performance (C2), stakeholder satisfaction (C5) and value creation and profitability (C6) with respect to the negative values of ri-c, are known in the cluster of disabled criteria.

The causal criteria that have the greatest impact on other criteria and therefore should be used in designing an effective reward system are: knowledge and ability to use it (C6), creativity and innovation (C3), professional ethics ( C8) and teamwork (C4). But since the DEMATEL method is a tool that is used always to identify the internal relationships between concepts than rather than rank them Therefore, it is necessary to prioritize the four criteria of identified causes by using a complementary multi-criteria decision method. For this purpose, the fuzzy quality performance expansion approach is used.

\section{Clustering the expected consequences of the implementation of the reward plan.}

In this part of the research, the 9 expected consequences of the implementation of the reward plan, which are extracted from the qualitative part, are clustered using the DEMATEL method to identify the most effective consequences. In addition to clustering, data analysis using DEMATEL helps to evaluate the expected consequences of the implementation of the reward plan and identify their internal relationships. In this step, the consequences are divided into two groups: cause and effect consequences. And because consequences are entered due to their greater importance in the ranking process by using fuzzy quality performance expansion. In the following, data analysis using DEMATEL method is presented.

\section{Formation of a matrix of direct impact of the expected} consequences of the implementation of the reward plan

In this step, first, using the expected consequences of the implementation of the reward plan presented in Table 3, experts were asked to in order to determination of impacts of each of the expected consequences on the others and to identification the internal relationship among 
these consequences by DEMATEL, express their opinion about the impact of each of the consequences on the other consequences and with the numbers 0 (no impact), 1 (low impact), 2 (high impact) and 3 (very high impact). Then the arithmetic mean led to summarize the opinions of experts. Table 9 summarizes the opinions of experts in this regard.

\section{Discussion}

The main purpose of this study was to identify and rank reward allocation criteria in companies and construction projects. In this regard, during the research process, the following measures were taken to achieve the research goal and answer these questions: In this regard, a large number of reward allocation criteria were identified from the literature.

In this case, with the help of semi-structured interviews with construction industry experts who had sufficient experience and knowledge in the implementation of the reward plan, the most important criteria that can be used in construction projects were identified. In order to prioritize the above criteria, it was necessary to identify the expected consequences of the implementation of the reward plan in order to prioritize the reward allocation criteria based on these consequences. The expected consequences of the implementation of the reward plan were also identified with the help of semi-structured interviews.

In this regard, by using interviews and questionnaires from face-to-face meetings with experts and then using DEMATEL method, the expected criteria were clustered and then the criteria and causal consequences which had more impacts were identified. In fact, the most important reason for using DEMATEL, in addition to identifying the internal relationships among the criteria, is to identify the criteria that are known as the criteria of the cause and also affect other criteria, ie the effect criteria. Another reason for clustering reward allocation criteria and using causal criteria in the continuation of the research process is the fact that interviews with industry experts show that designing a reward system with a wide variety of criteria is very difficult and inefficient, and impose a heavy cost of performance evaluation on the organization. Therefore, the use of DEMATEL and clustering of criteria helps, in addition to reducing the number of used criteria, due to the use of causal and vital criteria, the role of other criteria is also indirectly considered.

In this regard, while benefiting from the face-to-face meeting with experts and questionnaires prepared using the fuzzy quality expansion approach as a complementary method, reward allocation criteria were ranked. It is worth noting that the present study is innovative in two aspects. The first aspect is the identification and ranking of reward allocation 
criteria in construction projects, which has received less attention due to the nature of this industry and projects, and the second aspect is to provide a mixed qualitative and quantitative approach that in addition to identifying and ranking reward allocation criteria and Identifying the consequences of reward plan implementation also helps to identify the internal relationships between criteria and consequences. In this section, it is tried to answer the research questions in form of the description of the research findings. With a comprehensive review of the literature on reward allocation criteria, the following 16 criteria were identified as the most widely used reward allocation criteria:

- Quantity of tasks; - Quality of tasks; - Hours of presence at work; - Cooperation and teamwork; - Effectiveness; - Performance; - Profitability; - Efficiency; - work experience; - working conditions; - Discipline; - creativity and innovation; - Skills and knowledge; - Ethics; - stakeholders satisfaction; - education;

The results of conducting semi-structured interviews with experts and analyzing the data obtained from the interviews using the theme analysis method show that the following 8 criteria are the most important criteria in reward allocation in construction projects:

- Project performance; - doing duties; - creativity and innovation; - team work; stakeholders satisfaction; - Knowledge and ability to use it;- Profitability and value creation; - Ethics;

It should be noted that out of 13 criteria extracted from the interviews, 5 criteria were again removed with the consideration of experts' opinion, which can be considered as a kind of innovation and localization of the subject. These criteria are : changeability spirit, quality of work, duration of presence in the organization, level of experience and level of education. In addition, the criterion of quality of work performance was removed from the criteria because its evaluation is usually synonymous with performing the assigned tasks and in accordance with the criteria of performance evaluation and stakeholder satisfaction. The three criteria of length of presence in the organization, level of experience and level of education, although used in many companies as criteria for reward allocation, but since the reward is related to nonfixed payment, and the criteria of length of presence in the organization, the level of experience and the level of education are usually included in the payments and fixed salaries of individuals, were eliminated from the final criteria.

The results of the analysis of the data obtained from the interviews with the experts show that there are other themes that need to be considered. One of the most important themes discovered from qualitative data is the expected consequences of reward plan implementation. In fact, the results of the interviews showed that it is not possible to prioritize the reward 
allocation criteria without considering the results of its implementation. This means that first the managers' priority in implementing the reward plan must be determined, then the criteria for reward allocation must be prioritized and the reward plan must be implemented. According to the research findings, the most important consequences of the implementation of the plan are:

- Increasing employee motivation and job satisfaction; - Establishing organizational justice; - Improving customer and stakeholder satisfaction; - Improve effectiveness;Increase safety; - Promoting creativity and innovation; - Improving Performance; Increase profitability; - Learning and personal growth of employees;

The results of this research are in line with the following research. Yang and Chen (2018) in them study presents a new payment system for active team members in each project. Performance evaluation is performed without specifying a specific criterion and based on judgments made with the help of fuzzy linguistic variables. In this system, four models are proposed for different project management conditions. Maslahi and Zafar Khan (2019) have studied the factors affecting the productivity of employees in construction projects and in spite of considering factors such as temperature, relative humidity, type of work and the method used. They have not pointed to the factors like payment and reward and its effect on the efficiency.

Findings of the research after examining the internal relationships between reward allocation criteria and their clustering using the DEMATEL method show that among the final 8 criteria, knowledge and ability to use it, creativity and innovation, professional ethics and teamwork will be placed in the causal criteria cluster. And the criteria of project performance, task performance, stakeholder satisfaction and value- profitability creation are placed in the cluster of effect criteria. Also, although the DEMATEL method is not commonly used for ranking and its function is to examine the internal relationships between the factors of a system, but from the output of this method, the factors that should be considered more can be identified. This is done by identifying the factors that generally have the greatest impact on the system and receive the most impact from the system. Accordingly, the results of data analysis using the DEMATEL method show that the criteria of stakeholder satisfaction, professional ethics, teamwork and profitability and value creation have the greatest impact on the system and the most impact from the system.

Also, findings of the research after examining the internal relationships between the expected consequences of the reward plan implementation and their clustering using the DEMATEL method show that among the 9 consequences, the learning and personal growth of 
employees, promoting creativity and innovation, increasing safety and establishment Organizational justice is placed in the cluster of causal consequences. And the consequences of increasing employee motivation and job satisfaction, improving customer and stakeholder satisfaction, improving effectiveness, improving efficiency and increasing profitability are placed in the cluster of effect consequences.

The results of this research are in line with the following research. Cornellison et al. (2020) in their research show that employee satisfaction was higher in jobs where performancebased pay was implemented than in other jobs. They then propose a model in which employees with greater ability and higher risk tolerance receive greater rewards through performancebased pay. With the implementation of this model, employee satisfaction was assessed equally in all jobs, but employees in jobs that were paid based on performance and had a higher risk tolerance, expressed higher satisfaction. Onishi (2020) examines the effects of service compensation schemes on Research and Developement Organization of Japan staff innovations. In this research, the evaluation criterion is the criteria based on income and innovation and the results show that monetary incentives based on the performance of inventions, lead to increasing the motivation of innovative employees.

Likewise, the results of data analysis using DEMATEL method show that the consequences of improving efficiency, learning and personal growth of employees and improving effectiveness have a high impact on other factors and a high impact from other consequences of the implementation of the plan and therefore should be considered. After identifying the effective criteria and consequences, by determination the relationship between each of the criteria and expected consequences, as well as the correlation between the criteria and determining the importance of the consequences for managers, the reward allocation criteria were ranked. The results of this ranking show that the criterion of having professional ethics is the most important criterion for reward allocation. After this criterion, is the criterion of teamwork. After these two criteria are the criteria of creativity - innovation and knowledgeability to use it, respectively. These findings show that considering the work environment of construction projects, maintaining discipline and having organizational commitment and helping others is very important.

\section{Conclusion}

According to the results, it can be said that the professional ethics is the most important criterion for reward allocation to the employees in the construction projects. findings show that considering the work environment of construction projects, maintaining discipline and having 
organizational commitment and helping others is very important. Also, having the spirit of teamwork and cooperation with others is very important for working in such environments.

One of the notable points in the findings of this study is the less attention paid by construction managers to the use of labor quantity measurement indicators as a criterion for reward allocation and more attention to quality criteria such as professional ethics, creativity, etc., which shows the difference between the nature of the work and the end product of this industry with manufacturing industries such as parts manufacturing.

\section{References}

Abbasi, B., Arian, Gh., Ali, D., Parivash., J. (2018). Qualitative research on the effect of commercialization approach on traditional values of the university. Scientific-Research Quarterly of Science and Technology Policy. 2(2), 63-76.( in Persian). https://www.sid.ir/en/journal/ViewPaper.aspx?id=174537

Bottani, E., Rizzi, A. (2016). "Strategic management of logistics service: a fuzzy QFD approach". International Journal of Production Economics, 103(2), 585-599. ttps://doi.org/10.1016/j.ijpe.2005.11.006

Braun, V., Calrke, V. (2016). "Using thematic analysis in psychology". Qualitative research in psychology, 3, 77-101. https://www.tandfonline.com/doi/abs/10.1191/1478088706qp063oa

Chai, C. S. (2019). "A performance evaluation model by integrating fuzzy AHP and Fuzzy TOPSIS methods". expert systems and applications, 37, 7745-7754. https://doi.org/10.1016/j.eswa.2010.04.066

Davoodifar, M. (2016). "Designing and explaining the performance evaluation model of Dana Insurance Branch using data covering analysis technique". Master Thesis, Tarbiat Modares University, Iran. ( in Persian).

Gabus, A., Fontela, E. (1972). "World problems, an invitation to further thought within the framework of DEMATEL", Battelle Geneva Research Centre, Switzerland Geneva. https://www.scienceopen.com/document?vid=f6e5887c-7f0c-4303-837958fe891eeb03

Ho-Won, J. (2001). "A linear programming model deal by with ordinal rating in policy capturing of performance appraisal". European Journal of operational research, 134, 493-497. 
https://econpapers.repec.org/article/eeeejores/v_3a134_3ay_3a2001_3ai_3a3_3ap_3a 493-497.htm

Kvale, S. (1996). "Interviews: An introduction to qualitative research interviewing". London: Sage Publications. https://journals.sagepub.com/doi/abs/10.1177/109821409801900217?journalCode=aje c

Lai, Diana N.C., Min Liu, and Florence Y.Y. Ling. (2020). "A comparative study on adopting human resource practices for safety management on construction projects in the United States and Singapore". International journal of project management, 29, 018-1032. https://doi.org/10.1016/j.ijproman.2010.11.004

Lee, D.J. \& Ahn, J.H. (2017). "Rewards systems for intra-organizational learning knowledge sharing". European journal of operations research, 180, 938-956. Sharing. https://ideas.repec.org/a/eee/ejores/v180y2007i2p938-956.html

Mattis, Robert, L ., And John Jackson. (2018). "Human Resource Management". translated by Nasser Mirsepasi, Tehran: Mir Publications.( in Persian).

Merriam, S. B. (1988). "Case study research in education: a qualitative approach". San Francisco :Jossey-Boss.

Moselhi O., and Zafar, K. (2019). "Analysis of labor productivity of formwork operations in building construction". Construction Innovation, 10(3), 286-303. DOI: $\underline{10.1108 / 14714171011060088}$

Nematbakhsh, M., Babak, S., Pedram, R., Ali, Sh., Homayoun, N. (2016). "Study of the views of clinical faculty members of the Faculty of Medicine of Isfahan University of Medical Sciences regarding the effects of reward plan on medical education in teaching hospitals". Developmental steps in medical education, 3(2), 69-77.( in Persian). http://jmed.ssu.ac.ir/article-1-167-fa.pdf

Ofili, C., Mathhias, U. (2014). "Compensation System In Nigerian Construction Firm". MA dissertation, ST. Clements University.

Onishi, K. (2020). "The effects of compensation plans for employee inventions on R\&D productivity: New evidence from Japanese panel data". Research Policy, 42, 367-378. DOI: 10.1016/j.respol.2012.09.001

Saunders, M., Philip, L., and Adrian, T. (2018). "Research Methods for Business Students". (Fifth edition). London: Prentice Hall.

Sepehri Rad, A. (2019). "Designing a Mathematical Model of reward payment of Employees of the Organization- 360 Degree Performance Evaluation Approach - case study: 
National Productivity Organization". Master Thesis, Tarbiat Modares University, Iran. (in Persian).

Valipour, F. (2018). "Providing a framework for evaluating employee performance using 360degree method and Vikor technique", Case study of Jahad Keshavarzi Engineering Research Institute. M.Sc. Thesis, University of Tehran, Iran. (in Persian).

Wang, S. L. (2014). "Incentive Compensation: Bonusing and Motivation", MA dissertation, Massachusetts Institute of Technology.

Yang, T., Chiu-Wen, Ch. (2018). "An incentive pay system for project management based on responsibility assignment matrix and fuzzy linguistic variables". Expert Systems with Applications, 36, 12585-12591. http://etds.lib.ncku.edu.tw 